
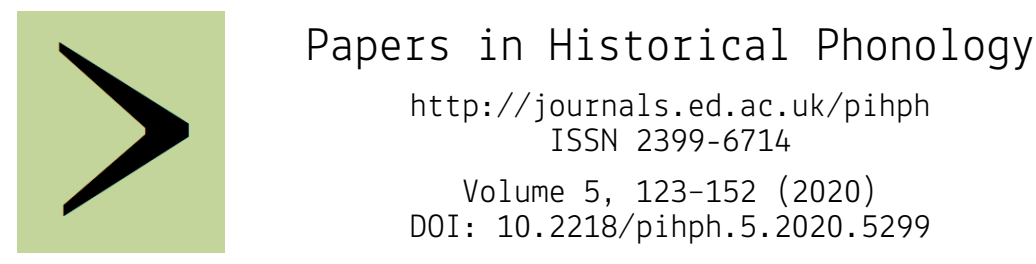

DOI : 10.2218/pihph.5.2020.5299

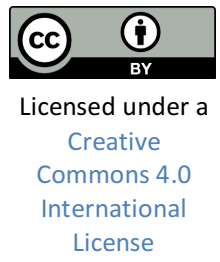

\title{
Arguing Spanish voseo tuteante verb endings: learning, variation and history with $\mathrm{OT}$
}

\author{
MIGUEL VÁZQUEZ-LARRUSCAíN \\ University of Southeastern Norway
}

\begin{abstract}
The full historical trajectory of voseo (second plural) forms becoming (deferent) second singular forms - as in Latin vos amātis (2pl) > Medieval Spanish vos amádes (2sg formal) - is a central chapter in the history of Spanish. In many Latin-American Spanish vernaculars, classical voseo fused with the original tuteo, giving rise to a new neutral address paradigm, voseo tuteante (Pre-classical Spanish voseo: vos amádes, amáes, amáis, amás (2sg formal) > Latin-American Spanish voseo tuteante: vos amáis, amás (2sg informal)). After a process of selection from the available options, four sets of endings have survived in those varieties: (áis, éis, ís / ás, és, ís / áis, ís, ís / ás, ís, ís). Why these four? The analysis proposed here builds on global properties of the verb system: (i) the verb suffix -is definitively replaced -des in the second half of the XVII century and the early XVIII century, and (ii) the four sets of endings now extant are exactly the ones that can be learned by Optimality-Theoretic grammar-inductive algorithms. This analysis supports the generative view that only languages with learnable grammars are passed on to future generations. Unlearnable languages are most likely to be lost over time. Similarly, variation is also constrained by the limits set by learnability conditions.
\end{abstract}

\section{Introduction}

From its very beginning, Spanish had a distinction between informal and polite forms of address - a contrast between $\mathrm{T}$ and $\mathrm{V}$ values (see Brown \& Gilman 1960), respectively realized through TU and VOS grammatical forms in pronouns and verbs, as in tú sabes 'you know' versus (señora), vos sabéis '(milady), you know'. In many European languages, there is a prototypical correspondence between politeness and its exponents, such that $\mathrm{T}$ values go together with TU forms and $\mathrm{V}$ values with VOS. TU and VOS refer, of course, to the corresponding Latin paradigms, their descendants and their equivalents. As is well known, such prototypical systems of address are historically motivated 
and rely on a seemingly natural cognitive metaphor that equates the notion of 'power' with 'plurality', as well as triggering a train of intuitive associations like 'more is bigger', 'big is mighty' and 'mighty is honorable'. Linguistic changes in some European languages have blurred those prototypical correspondences inherited from Late Latin in different ways. For instance, oral registers of Spanish in South and Central America have systems where informal $\mathrm{T}$ values are now codified not by the traditional TU morphology but by a hybrid grammatical system combining both TU and VOS forms, henceforth referred to as VOS+TU, or $\mathrm{VOS}^{\mathrm{T}}$ for short. This hybrid pattern is referred to here as voseo tuteante, in contrast to the prototypical system, which is referred to as voseo. The prototypical system is preserved as voseo reverente, a very formal option in synchronic terms. ${ }^{1}$ VOS $^{\mathrm{T}}$ systems are widespread across national borders in LatinAmerican Spanish vernaculars all the way from the continental southern tip of Tierra del Fuego in Argentina to the southern Mexican states of Chiapas and Tabasco. ${ }^{2}$

The main goal of this paper is to ascertain which structural conditions allow the variable systems of voseo tuteante to appear, consolidate and vary in the way that they $\mathrm{do}^{3}-$ see $(1: \mathrm{VI})$, below. The whole story is quite complex, involving both phonological and morphological change, but the topic can be circumscribed under the proper degree of idealization that keeps data manageable and theoretically interesting. In what follows, section 2 gives a general background to the history and dialectology of TU and VOS forms in Spanish, section 3 describes the results of previous work on the phenomenon from a traditional philological perspective, section 4 places limits on the data to be considered and shows why a parametric approach to explanation fails, and sections 5 and 6 set out a novel Optimality-Theoretic analysis of the developments, involving a set of phonological and transderivational constraints and a consideration of learnability, based on OT-based formal learning theory. Section 7 concludes.

\footnotetext{
1 In Vázquez-Larruscaín et al. (2019), those VOST hybrid paradigms with T values are referred to as voseo tuteante, introducing alternative terminology to what is usual practice in reference works like NGLE or DPD, i.e. voseo (dialectal) americano.

2 With the exception of Argentina (BAAL 1982), VOST systems lack official recognition. Voseo tuteante is usually the L variety in diglossic situations in which the $\mathrm{H}$ variety is reserved for tuteo (See Ferguson 1959 for the term diglossia and the notation L for low prestige variety and $\mathrm{H}$ for high prestige).

3 For expository convenience, mixed agreement systems, like tú sabés, or vos sabes, will not be taken into consideration, since verb variability in those systems is always contained within the simpler voseo tuteante varieties examined here (VázquezLarruscaín et al. 2019).
} 


\section{TU and VOS forms in Spanish}

Voseo tuteante is historically innovative and variable, with four different sets of verb endings. For comparative purposes, $\mathrm{VOS}^{\mathrm{T}}$ endings are given in (1) together with other patterns of second person address, singular or plural, formal or informal. These other second person patterns include the normative tuteo exclusivo in (1:I), uniform all over the Spanish-speaking world, and the old pattern of classical voseo (1:II), which has survived as a literary voseo reverente (see $D P D$ for this terminology), restricted now to frozen styles. The verb paradigm of the classical voseo is, furthermore, identical to the paradigm of vosotros (1:III), which is still preserved in the literary norm and in the vernacular of most forms of European Spanish (as second person plural in informal situations). The vosotros system is otherwise unknown in the rest of the Spanish-speaking world (1:V), being replaced by ustedes (which thus becomes the universal second plural everywhere but in Spain).

The verb paradigms of both voseo reverente and vosotros ultimately derive from Latin VOS forms: Modern Spanish vos teméis, vosotros teméis < Medieval Spanish vos temedes < Latin vos timētis. Formal identity between polite second singular and second plural was the only way to codify formal address in western European languages before the Renaissance, right before the Spanish empire began its transatlantic expansion over the American continent (Páez-Urdaneta 1981). At that time, a new system of deference (now the common way to express politeness wherever Spanish is spoken) evolved out of third person formulas, which are from now on referred to as usted and ustedes - see (1:IV,V), respectively.

(1) Second person patterns (singular/plural, formal/informal)

\begin{tabular}{|c|c|c|c|c|}
\hline \multicolumn{2}{|c|}{ I. tuteo (2sg, informal) } & cantas & temes & vives \\
\hline \multicolumn{2}{|c|}{ II. voseo reverente ( $2 \mathrm{sg}$, formal) } & cantáis & teméis & vivís \\
\hline \multicolumn{2}{|c|}{ III. vosotros (2pl, informal, Spain) } & cantáis & teméis & vivís \\
\hline \multicolumn{2}{|c|}{ IV. usted (3sg formal) } & canta & teme & vive \\
\hline \multicolumn{2}{|c|}{ V. ustedes (3pl) } & cantan & temen & viven \\
\hline \multicolumn{2}{|c|}{ The three verb classes of Spanish: } & CANTAR & TEMER & VIVIR \\
\hline \multirow{4}{*}{$\begin{array}{l}\text { VI. voseo } \\
\text { tuteante } \\
\text { (2sg, } \\
\text { informal) }\end{array}$} & a. monophthong pure & cantás & temés & vivís \\
\hline & b. monophthong mixed & cantás & temís & vivís \\
\hline & c. diphthong pure & cantáis & teméis & vivís \\
\hline & d. diphthong mixed & cantáis & temís & vivís \\
\hline
\end{tabular}


All voseo tuteante systems in (1:VI) ultimately derive from the old classical voseo forms in (1:II), under heavy pressure from usted as an alternative polite form in the XVII and XVIII centuries. Thus, the whole chain of historical events must not only keep track of phonological and morphological changes but also consider changes in the politeness values associated to them. All this makes the history of voseo a complex one. However, a manageable account is possible if phonology and morphology are kept separate from pragmatics. My goal is to clarify how the prototypical voseo forms of the XIV century (vos cantades, timedes, vivedes) ended up giving four alternative sets of verb endings in Latin-American voseo tuteante from the middle of the XVIII century. In particular, my main question is this: which structural conditions motivated the selection of the four surviving sets in $(1: \mathrm{VI})$ to the detriment of others that could have been good candidates for transmission to future generations? For instance, the set *\{cantáis, temés, vivís\}, not in use today, seems to be one of the most popular options reconstructed for voseo in the XVI century (de Sousa 1964, Cuervo 1893, 1911, Fontanella de Weinberg 1976).

Variation was considerable in the second half of the XV and early XVI centuries (Cuervo 1893). From the variation in documents of the period, schematised in (2), the number of potential combinations is $3^{*} 3=9$, if history were to pick one variant from each verb class at random, even if forms with intervocalic $-d$ - in the ending are excluded from the reckoning. From this potential set of nine sets, the total of attested varieties is only four. Why those four? Was it a contingent outcome or were there any deep structural conditions guiding the changes? Did change take place piecemeal for each ending or did a global process affect the entire verb system comprising its three classes? Those questions are in focus here.

(2) Variable VOS inflections from Latin to XV century Spanish ${ }^{4}$

\begin{tabular}{l||c|c|cc|c}
\multirow{2}{*}{ LATIN } & CANTĀRE & TIMĒRE & CADĔRE & VĪVĔRE & VENĪRE \\
\cline { 2 - 6 } & cantātis & timētis & cadĕtis & vīvĭtes & venītes \\
\hline \hline \multirow{2}{*}{ SPANISH } & $\begin{array}{c}\text { CANTAR } \\
\text { 'to sing' }\end{array}$ & $\begin{array}{c}\text { TEMER } \\
\text { 'to fear' }\end{array}$ & $\begin{array}{c}\text { CAER } \\
\text { 'to fall' }\end{array}$ & $\begin{array}{l}\text { VIVIR } \\
\text { 'to live' }\end{array}$ & $\begin{array}{c}\text { VENIR } \\
\text { to come' }\end{array}$ \\
\hline \multirow{2}{*}{ XIII } & cantades & temedes & cadedes & vivides & venides \\
\hline \multirow{2}{*}{ XV } & cantades & temedes & cadedes & vivides & venides \\
& cantaes & teméis & caéis & vivís & venís \\
& cantáis & temés & caés & & \\
& cantás & temís & caís & &
\end{tabular}

${ }^{4}$ Lausberg (1962, sections 868-875). 
At the beginning of the classical period, all forms derived from Latin VOS were in flux (Lapesa 1970). The material in (3) gives a first approximation of the historical course of events, showing how the variability found in the XV and XVI centuries gave rise to a new distribution of forms and values in Spanish during the XVII and XVIII centuries, as modern Spanish was taking definitive shape. In the new emerging literary norm, variability was highly reduced, with a more stable and univocal reassignment of forms to values. Variants with no specific value were bound to disappear from the literary norm, even though we must suppose that most of them were nevertheless retained in the oral registers (because they would reappear in the XIX and XX centuries), already transformed as part of the voseo tuteante system. Forms and usages without historical continuity are struck through in (3). Anticipating my analysis, cantades and cantaes are definitively lost by the late XVII century, once the verb ending had been arguably reinterpreted as -is (/cant+á+is/) instead of -des (cant+á+des). ${ }^{5}$ The split between plural vosotros in (3b) and formal vos in (3a) is well described in Calderón-Campos (2010).

(3) All patterns with etymological roots in Latin VOS, after XVII century

\begin{tabular}{l||l|l|l}
$\begin{array}{l}\text { a. VOS } \\
\text { (formal, frozen } \\
\text { style) }\end{array}$ & vos cantáis & vos teméis & vos vivís \\
& $\begin{array}{l}\text { vos cantás } \\
\text { vos cantades } \\
\text { vos temís }\end{array}$ & vos vivides \\
\hline \hline $\begin{array}{c}\text { b. VOSOTROS } \\
\text { (2pl, informal, } \\
\text { Spain) }\end{array}$ & vosotros cantáis & vos temedes & \\
& vosotros cantás & $\begin{array}{l}\text { vosostros temés } \\
\text { vosostros temís }\end{array}$ & vosotros vivides \\
\hline \hline $\begin{array}{c}\text { c. VOS+TU } \\
\text { (2sg, informal, } \\
\text { highly variable) }\end{array}$ & vosotros cantades & vos vivís \\
vosotros cantaes & vosostros temedes & \\
\hline & & $\begin{array}{l}\text { vos teméis } \\
\text { vos temés } \\
\text { vos temís }\end{array}$ & vos vivís \\
& & &
\end{tabular}

5 These most archaic forms with -des, struck out in (3), were still preserved in the traditional dialects of Asturian-Leonese (an independent linguistic group between Galician-Portuguese and Castilian-Spanish) in the second half of the XX century (Zamora Vicente 1960). 
As a general guide, I give a fairly schematic illustration of the most relevant stages of the whole historical process in (4), distinguishing three main periods: (4a) from Latin to pre-classical Spanish, (4b) the normalization of literary Spanish, and (4c) the main linguistic varieties in the Spanish-speaking world at present (Lapesa 1981).

Variation first appeared in the XV century. Most of those variants presumably survived in the spoken registers over the ensuing three or four centuries, until they finally reappeared in the XIX and XX centuries as part of many spoken varieties widespread over South and Central America. All stages in (4) are well documented, except for stage (4b2), for which there is scant and fragmentary evidence in the written records.

(4) From 2pl to 2sg formal and from 2sg formal to 2sg informal

(a) I-XV

\begin{tabular}{|c|c|c|c|c|}
\hline & $2 \mathrm{pl}$ formal & $2 \mathrm{pl}$ informal & $2 \mathrm{sg}$, formal $=\mathrm{V}$ & $2 \mathrm{sg}$, informal $=\mathrm{T}$ \\
\hline 1. Latin & vos timētis & & tu timēs & \\
\hline 2. Late Latin & \multicolumn{3}{|l|}{ vos timētis } & tu timēs \\
\hline $\begin{array}{l}\text { 3. Medieval } \\
\text { Spanish }\end{array}$ & \multicolumn{3}{|l|}{ vos temedes } & tú temes \\
\hline $\begin{array}{l}\text { 4. Pre-classical } \\
\text { Spanish } \\
\text { (XIV-XVI) }\end{array}$ & \multicolumn{3}{|l|}{$\begin{array}{l}\text { vos temedes } \\
\text { vos temés } \\
\text { vos teméis } \\
\text { vos temís }\end{array}$} & tú temes \\
\hline
\end{tabular}

(b) XVI-XVIII

\begin{tabular}{|c|c|c|c|c|c|}
\hline $\begin{array}{l}\text { 1. Classical } \\
\text { Spanish } \\
\text { (XVII) }\end{array}$ & $\begin{array}{l}\text { ustedes } \\
\text { temen }\end{array}$ & $\begin{array}{l}\text { vosotros } \\
\text { teméis }\end{array}$ & $\begin{array}{l}\text { usted } \\
\text { teme }\end{array}$ & $\begin{array}{l}\text { vos } \\
\text { teméis }\end{array}$ & $\begin{array}{l}\text { tú } \\
\text { temes }\end{array}$ \\
\hline $\begin{array}{l}\text { 2. Classical } \\
\text { Spanish } \\
\text { (XVII-XVIII, } \\
\text { oral, non- } \\
\text { standard) }\end{array}$ & $\begin{array}{l}\text { ustedes } \\
\text { temen }\end{array}$ & $\begin{array}{l}\text { vosotros } \\
\text { teméis } \\
\text { (vosotros } \\
\text { temís, temés) } \\
\text { (ustedes } \\
\text { teméis, temís, } \\
\text { temés) }\end{array}$ & $\begin{array}{l}\text { usted } \\
\text { teme }\end{array}$ & $\begin{array}{l}\text { vos } \\
\text { teméis } \\
\text { (vos } \\
\text { temés, } \\
\text { temís) }\end{array}$ & tú temes \\
\hline
\end{tabular}




\section{(c) XVIII-XXI}

\section{Spain}

\begin{tabular}{|c|c|c|c|}
\hline $\begin{array}{l}\text { 1. Non-voseo } \\
\text { Spanish (Spain) } \\
\text { (XVIII-XXI) }\end{array}$ & $\begin{array}{l}\text { ustedes } \\
\text { temen }\end{array}$ & $\begin{array}{l}\text { vosotros } \\
\text { teméis } \\
\text { (ustedes } \\
\text { teméis) }\end{array}$ & usted teme \\
\hline
\end{tabular}

\section{General Spanish (Latin-America)}

\begin{tabular}{l||l|l|l}
$\begin{array}{l}\text { 2. Spanish (Mexico, } \\
\text { Perú, Caribbean) } \\
\text { (XIX-XXI) }\end{array}$ & ustedes temen & tú temes \\
\end{tabular}

\section{Latin-American Spanish (voseo tuteante)}

\begin{tabular}{|c|c|c|c|}
\hline $\begin{array}{l}\text { 3. Voseo Spanish } \\
\text { (Central American, } \\
\text { Southern Cone, } \\
\text { Interior Andes ...) } \\
\text { (XVIII-XXI) }\end{array}$ & ustedes temen & usted teme & $\begin{array}{l}\text { vos temés, } \\
\text { teméis, temís } \\
\text { (vos temes) } \\
\text { (tú temés, } \\
\text { temís, teméis) }\end{array}$ \\
\hline
\end{tabular}

\section{The State-of-the-Art}

In spite of its significance for the dialectology and the history of Spanish, there are not many studies tracing in detail how voseo tuteante evolved and the number of significant contributions on the topic is not very numerous (Cuervo 1893, Dworkin 1988, Fontanella de Weinberg 1976, Lapesa 1970, Malkiel 1949, Rini 1996, Rona 1967, and a few others). This is most likely due to the scarcity of written records for the oral varieties during the three centuries in the formative period (Bertolotti 2015). Previous studies have been quite successful in philologically tracking relevant empirical material for the variability of voseo, both in the pre-classical period and in contemporary dialects. Their theoretical ambition, however, is rather tentative, seldom conclusive. It is also remarkable that this topic has not received any attention whatsoever among generative linguists in the last fifty years - neither transformational, natural, parametric nor optimalitytheoretic. One might suspect that this lack of attention is due to the hybrid character of the data, which blends forms from different paradigms (Fontanella de Weinberg 1977), as shown in (5), where voseo tuteante (bold and underlined) fuses classical voseo (bold) and tuteo exclusivo (underlined), together with by now unique verb forms like acordás. ${ }^{6}$

\footnotetext{
${ }^{6}$ All mean 'now you do not remember your friends'. (5b) is formal address in a frozen style.
} 
(5) The hybrid nature of voseo tuteante.

a. Vos, amigo, ya no te acordás de tus amigos.

(voseo tuteante)

b. Vos, señor, ya no os acordáis de vuestros amigos. (voseo reverente)

c. Tú, amigo, ya no te acuerdas de tus amigos.

(tuteo)

A great deal of effort has been invested in explaining what is now idiosyncratic, e.g. acordás, cantás, temés or temís, but not what voseo tuteante shares with both voseo clásico and vosotros, in forms like acordáis, cantáis, or teméis. No previous study has tried to explain the selection of sets of endings as something conditioned by the structure of the verb system taken as a whole. On the contrary, analogical relations have always been posited as chance events. Verb endings have been studied in a piecemeal fashion, principally from a phonetics-first perspective, with analogy considered as a last resort. The chapter describing the chronology of how variability arose in the XV century and how it was reinterpreted, eliminated, or otherwise selected, transmitted and transformed into voseo tuteante is yet to be written (see Granda 1978, nevertheless, for interesting thoughts on the variability and the history of the voseo tuteante systems at large). My approach, in contrast to this venerable but outdated tradition, is decidedly systemic. I ask why the course of events produced the variability actually attested and why it did not produce any of the other patterns that (in spite of being historically plausible and realistic) are nonetheless nowhere to be found in the synchronic record. (6) sets out both attested and unattested (but plausible) patterns in voseo tuteante.

(6) Attested and unattested patterns in voseo tuteante

\begin{tabular}{l||l|l|l|l} 
1. unattested & cantáis & temés & vivís \\
\hline \multirow{2}{*}{\begin{tabular}{l} 
2. unattested \\
\hline \multirow{2}{*}{$\begin{array}{l}\text { attested } \\
\text { forms }\end{array}$}
\end{tabular}} & cantás & teméis & vivís \\
\cline { 3 - 5 } & b. monophthong pure & cantás & temés & vivís \\
\cline { 2 - 5 } & c. diphthong pure & cantáis & teméis & vivís \\
\cline { 2 - 5 } & d. diphthong mixed & cantáis & temís & vivís
\end{tabular}




\section{Circumscribing the data}

The analysis needs to be precise as to which parts of the material will count as primary data and which parts provide complementary or additional evidence. Two clarifications are necessary to help the reader follow the two final sections. On the one hand, this paper deals with the phonological and morphological side of the evolution of voseo in general, leaving aside the parallel changes undergone by the pragmatic system. The main pragmatic change is that voseo tuteante is used only for informal address, even though most of its linguistic elements, both pronouns and verbs, derive from forms previously used for polite address. The phonological changes, on the other hand, concern how old polite voseo forms like temedes (identical to the old second plural) were progressively supplanted by the variable teméis, temés or temís - now neutral morphological alternatives to address a second person singular in quite a number of Latin-American Spanish vernaculars.

The second observation has a more significant empirical impact on our understanding of the data, as it clearly introduces a distinction between input representations and grammar, which in addition brings up the issue of their respective role in guiding the transmission of voseo over the centuries. A fundamental thesis of our study will be that the suffix -is became the only verb ending for voseo, progressively substituting for the old ending -des, which is the direct descendent of the Latin second plural -tis. Therefore, when studying the emergence of voseo tuteante, the main historical reference will be not to a system that still retains the old -des, but to more advanced historical stages where the new ending -is had already been consolidated as the only one in use. In chronological terms, this stage occurred at the end of the XVII and beginning of the XVIII century (Cuervo 1893).

For reasons to be clarified below, it is also necessary to assume a largely undocumented intermediate stage in the big picture, see (4b2) above, where voseo in the spoken vernacular must have remained highly variable, unlike in the literary norm, where it was stable and uniform, see (4b1). This hypothetical, poorly documented, intermediate stage of the oral language plays the role of a necessary historical bridge between two well documented stages: the pre-classical stage of the late $\mathrm{XV}$ century, described in (4a4), and the contemporary stage of voseo tuteante, depicted in (4c3). The crucial period for the historical comparison is therefore the formative period of the classical varieties of Spanish, the stage schematically captured in (4b), which corresponds to the XVI and XVII centuries.

The stage with -is as the only input is a situation most likely well established for all tenses at the end of the XVII century and the beginning of the XVIII (Cuervo 1893). If we posit that -is functions as 
the only input in both the classical voseo of the XVIII and the voseo tuteante of today, the Optimality-Theoretic analysis that is to be proposed below can deal with the variability of the data exclusively in terms of structural conditions, without having to consider the role of the input in any comparison, either historical or typological. By keeping the input constant for both the historical antecedent in (4b) and the current variants in (4c3), all variation in the endings and their transmission will be seen to arise from differences in the ranking of constraints, where conditions for change must ultimately be found. ${ }^{7} \mathrm{~A}$ plausible diachronic scenario is presented in (7).

(7) From VOS -des to VOS $\{-d e s,-i s\}$ to VOS -is to $\operatorname{VOS}^{\mathrm{T}}$-is

\begin{tabular}{l||l|l|l|l} 
& Morphology & CANTAR & TEMER & VIVIR \\
\hline \hline a. XV & -des & $\begin{array}{l}\text { cantades } \\
\text { cantaes } \\
\text { cantáis } \\
\text { cantás }\end{array}$ & $\begin{array}{l}\text { temedes } \\
\text { teméis } \\
\text { temés } \\
\text { temís }\end{array}$ & $\begin{array}{l}\text { vivides } \\
\text { vivís }\end{array}$ \\
\hline \multirow{2}{*}{$\mathrm{b.XVI}$} & \multirow{2}{*}{-des, -is } & $\begin{array}{l}\text { cantades } \\
\text { cantaes } \\
\text { cantáis } \\
\text { cantás }\end{array}$ & $\begin{array}{l}\text { temedes } \\
\text { teméis } \\
\text { temés } \\
\text { temís }\end{array}$ & $\begin{array}{l}\text { vivides } \\
\text { vivís }\end{array}$ \\
\hline \multirow{2}{*}{ c. XVIII } & \multirow{2}{*}{-is } & $\begin{array}{l}\text { cantáis } \\
\text { cantás }\end{array}$ & $\begin{array}{l}\text { teméis } \\
\text { temés } \\
\text { temís }\end{array}$ & vivís \\
\hline \multirow{2}{*}{$\mathrm{d} . \mathrm{XXI}$} & \multirow{2}{*}{-is } & cantáis & teméis & vivís \\
\cline { 3 - 5 } & & cantáis & temís & vivís \\
\cline { 3 - 5 } & cantás & temés & vivís \\
\cline { 3 - 5 } & cantás & temís & vivís
\end{tabular}

A major consequence of eliminating -des as a verb ending is that forms like cantádes and cantá.es can now be safely discarded as relevant comparative data for any stage from the XVIII century onwards. The reason is straightforward: there are no realistic phonological mappings from inputs with -is to outputs with -es or -des

\footnotetext{
${ }^{7}$ From this point of view, accounting for the variation of the endings in the XV century would require a separate study, certainly related to the topic in focus here, but temporarily postponed.
} 
in the endings. Thus, a new underlying form like /cant+á+is/ is not an adequate morphological base for output forms like cantádes or cantáes under any reasonable system of phonological rules. It is thus the stage with the suffix -is as the only input that offers the proper historical precedent for the current stage of variable voseo tuteante in a straightforward manner. Under these premises, the four sets of endings in the contemporary vernaculars of Spanish appear as different choices in a grammatical system with two binary parameters, as in (8).

(8) Parametric choices in the history of Spanish 2 sg. (voseo varieties)

\begin{tabular}{c||c|c}
$\begin{array}{c}\text { Input: } \\
\text { (V-root)+ThV+is }\end{array}$ & \multicolumn{1}{|c}{$[$ +diphthong] } & [-diphthong] \\
\hline \hline [-convergent] & a) cantáis, teméis, vivís & c) cantás, temés, vivís \\
\hline$[+$ convergent $]$ & b) cantáis, temís, vivís & d) cantás, temís, vivís
\end{tabular}

One parameter deals with diphthongs, while the other deals with the neutralization of thematic vowels in the -er and -ir verb classes. This parametric system offers an account that can explain why we have the four systems we have, and similarly, why we do not have other conceivable systems that could have emerged by picking endings at random from the variability pool in (3) above. From this perspective, a parametric model makes much stronger claims than those of neogrammarian predecessors or structuralist and functionalist forerunners. Besides, the simplest formulation of the linguistic change also facilitates the identification of the three major properties defining the process: a morphological reinterpretation of the ending from -des to -is, and two parametric systemic options: tolerance for diphthongs (cantáis vs. cantás) and preservation of three classes of verb allomorphs (temés vs. temís).

In the last two sections, I will, however, discuss how Optimality Theory (Prince \& Smolensky 2004, henceforth OT) offers a deeper and theoretically more insightful analysis of the data than any rigid parametric contender. The convenience of an OT analysis can be anticipated by recognizing an apparently minor, almost negligible problem in the parametric account: why is vivís always a monophthong, especially when a system like (8) otherwise prefers diphthongs such as -áis or -éis (instead of monophthongs like -ás and -és)? Or, for that matter, why are diphthongs or monophthongs preferred over hiatus sequences, like*-á.is or *-é.is, which are unattested in any variety of Spanish? Furthermore, if new parameters

8 This is the analysis used in any reference grammar as well as in most technical literature, as in Roca (2010). 
are required to answer those and related questions in principled ways, how can the system, at the same time, prevent the proliferation of structural possibilities that would follow from adding new parameters to the system? The solution, in my mind, is a system with ranked structural conditions. For instance, the contracted monophthong of vivís, never yielding to potential alternatives *vivíis or *vivíis, obeys a universal condition against two adjacent identical high vowels, either in hiatus (*- $^{*}$ i.is) or as a diphthong ( ${ }^{*}$-iis). In Spanish, as in many other languages, this constraint against a sequence of two adjacent i's is always top-ranked, independent of other considerations.

\section{The Optimality-Theoretic alternative}

In this section, I argue that Optimality Theory offers a superior framework for the analysis of how voseo has been transmitted and of how history, variability and learning are connected. Two dimensions are significant: [ \pm diphthong] and [ \pm convergence], as set out in (8) above. I show below, however, that these two parameters need to be translated into interacting violable constraints. Optimality-Theoretic architectures, moreover, integrate a particular piece of analysis with the rest of the dimensions that shape the phonological and morphological system at large.

\section{$5.1 *$ DIPH}

A constraint against diphthongs in verb endings is responsible for the bifurcation of outputs with and without vowel sequences, say cantáis vs. cantás. $^{9}$ Variation in the output, if inputs are invariant, arises through the re-ranking of two major phonological constraints, *DIPH and ONSET, together with a general faithfulness constraint MAX-X, all of which are defined in (9).

(9) Basic constraints

a. *DIPH(THONG): avoid diphthongs

b. ONS(ET): all syllables begin with a consonant

(= two adjacent vowels should not be heterosyllabic)

c. MAX-X: input segments have a correspondent in the output

\footnotetext{
9 This constraint deals with variation in purely structural terms, ignoring the quite legitimate alternative of locating the source of variation in the input, distinguishing between a morph -is and a morph -s. If anything, a structural treatment, to the extent that is possible, is preferable to a lexical treatment. My reservations are not about whether a structural treatment is possible in all cases but about whether it is realistic. Once these reservations are put aside, the role of *DIPH is straightforward.
} 
Given these constraints, voseo varieties with monophthongs result from the sub-ranking ONSET >> *DIPH >> MAX-X, while varieties with diphthongs reverse the order of priorities onto a new sub-ranking such that ONSET >> MAX-X >> *DIPH. ONSET always dominates *DIPH in endings, because in any Spanish variety the thematic vowel of the verb and the ' $i$ ' of the suffix -is never make up heterosyllabic vowel sequences as in *cantá.is. With ONSET on top, variation depends on the ranking of MAX-X and *DIPH, as shown in (10). If faithfulness prevails, the result is a diphthong, as in cantáis; if not, only the thematic vowel survives, as in cantás.

(10) /cant+á+is/

(a) DIPH >> MAX-X

\begin{tabular}{|c||c|c|c|}
\hline cant+á+is & ONS & $*$ DIPH & MAX-X \\
\hline \hline cantás & & & $*$ \\
\hline cantáis & & $*$ & \\
\hline cantá.is & $*$ & & \\
\hline
\end{tabular}

(b) MAX-X >> *DIPH

\begin{tabular}{|c||c|c|c|}
\hline cant+á+is & ONS & MAX-X & $*$ DIPH \\
\hline \hline cantáis & & & $*$ \\
\hline cantás & & $*$ & \\
\hline cantá.is & $*$ & & \\
\hline
\end{tabular}

Monophthong-formation actually requires a more specific faithfulness constraint to protect the thematic vowel over the vowel of the ending -is, so that e.g. cantás is always a better option than *cantís for an input like cant+á+is, whenever the satisfaction of ${ }^{*}$ DIPH is stronger than faithfulness-to-the-input. The relevant constraint, MAX-ThV, (see (11) below) is a stringent version of the general faithfulness constraint MAX-X (Prince 1997, de Lacy 2006). Unlike MAX-X, which protects all segments in the input, MAX-ThV only protects the thematic vowels of verbs (Roca 2010). The stringent logical relation between the two MAX constraints follows from the fact that any violation of MAX-ThV also counts as a violation of MAX-X. 
(11) MAX-ThV: an input thematic vowel has an output correspondent

(a) *DIPH >> MAX-X (MAX-ThV)

\begin{tabular}{|c||c|c|c|c|}
\hline cant+á+is & ONS & $*$ DIPH & MAX-ThV & MAX-X \\
\hline \hline cantás & & & & $*(\mathrm{i})$ \\
\hline cantís & & & $*(a ́)$ & $*(a ́)$ \\
\hline cantáis & & $*$ & & \\
\hline cantá.is & $*$ & & & \\
\hline
\end{tabular}

(b) MAX-X >> *DIPH (MAX-ThV)

\begin{tabular}{|l||c|c|c|c|}
\hline cant+á+is & ONS & MAX-X & $*$ DIPH & MAX-ThV \\
\hline \hline cantáis & & & $*$ & \\
\hline cantás & & $*(\mathrm{i})$ & & \\
\hline cantís & & $*(a ́)$ & & $*(a ́)$ \\
\hline cantá.is & $*$ & & & \\
\hline
\end{tabular}

\subsection{II=III}

The second parameter, referred to as [ \pm convergence] in (8), becomes an output-to-output constraint in an OT environment, namely II=III, as defined in (12), requiring surface identity between the present indicative of verbs in the -er and -ir classes, so that temís mimics vivís.

(12) II=III: the output ending of class II is the same as in class III

This transderivational constraint is regularly violated in all varieties of Spanish except in the mixed types, as defined in (6), when vosotros or voseo second persons surface with the same ending (-is) in both -er and -ir verbs, giving temís and vivís. The most significant interaction involves this analogical constraint and faithfulness to the thematic vowel in the output. Mixed varieties result from the ranking II =III >> MAX-ThV, see (13c), while non-mixed varieties have rankings where either MAX-X or MAX-ThV dominate II=III, as shown in (13a,b). 
(13) Transderivational II=III

(a) MAX-X >> II=III

\begin{tabular}{|c||c|c|c|c|}
\hline tem+é+is & MAX-X & $*$ DIPH & II=III & MAX-ThV \\
\hline \hline teméis & & $*$ & $*$ & \\
\hline temés & $*$ & & $*$ & \\
\hline temís & $*$ & & & $*$ \\
\hline
\end{tabular}

(b) * DIPH $>>$ MAX-X $>>$ II $=$ III

\begin{tabular}{|c||c|c|c|c|}
\hline tem+é+is & $*$ DIPH & MAX-X & MAX-ThV & II=III \\
\hline \hline temés & & $*$ & & $*$ \\
\hline temís & & $*$ & $*$ & \\
\hline teméis & $*$ & & & $*$ \\
\hline
\end{tabular}

(c) II=III >> MAX-ThV, MAX-X

\begin{tabular}{|c||c|c|c|c|}
\hline tem+é+is & II=III & MAX-X & $*$ DIPH & MAX-ThV \\
\hline \hline temís & & $*$ & & $*$ \\
\hline temés & $*$ & $*$ & & \\
\hline teméis & $*$ & & $*$ & \\
\hline
\end{tabular}

\subsection{Anti-hiatus of identical vowels}

The fact that the ending of the third class is always a monophthong (-ís) is also accommodated in OT with a quite solid and natural constraint against sequences of two adjacent identical high vowels. This constraint, unlike its counterpart for non-high vowels, is always respected in all varieties of Spanish, so that the vowel sequences $*_{i}$.is and $*_{\text {iis }}$ are not well-formed anywhere. In other words, the sequence -i.is is found nowhere, unlike -é.es, which is unproblematic in careful speech, appearing in verb forms like cré.es 'you-believe' or 'lé.es' 'youread'. It seems appropriate to invoke a new stringent relationship between a general constraint against two identical vowels, either as hiatus or inside a diphthong, together with a specific constraint against a sequence of two identical vowels when those vowels happen to be [+high], as in (14). The Spanish facts, in any normative variety, follow from the sub-ranking ${ }^{*} \mathrm{~V}(\text { high })_{\mathrm{i}} \mathrm{V}(\text { high })_{\mathrm{i}}>\mathrm{MAX}-\mathrm{X}>{ }^{*} \mathrm{~V}_{\mathrm{i}} \mathrm{V}_{\mathrm{i}}$, so that $/ \mathrm{le}+\mathrm{e}+\mathrm{s} /$ ('you read') gives the heterosyllabic lé.es, while /viv+ítis/ is 
vivís, never *vivíis or *vivíis, and the input /le+é+is/ ('you-pl-read') can be either le.éis, le.és or le.ís, but never *le.é.is.

(14) Constraints against a sequence of two adjacent identical vowels
a. ${ }^{*} \mathrm{~V}_{\mathrm{i}} \mathrm{V}_{\mathrm{i}}$
avoid two adjacent identical vowels
b. $\quad *$ V(high) $)_{\mathrm{i}} \mathrm{V}(\text { high })_{\mathrm{i}}$
avoid two adjacent identical high vowels

Since the constraint against two adjacent i's is respected in all varieties of Spanish, it will not be used in the factorial typology of voseo endings. Any candidate with *-iis or *-í.is endings will always be harmonically bounded for language-specific reasons: the constraint against a sequence of two identical high vowels is always top-ranked in all Spanish varieties, formal or informal, in any geographical location.

$$
{ }^{*} V_{\text {i }}(\text { high }) V_{i}(\text { high })>>\ldots
$$

\begin{tabular}{|l||c|c|c|c|c|}
\hline & $* \operatorname{Vi}(\mathrm{h}) \operatorname{Vi}(\mathrm{h})$ & MAX-ThV & MAX-X & ${ }^{*}$ DIPH & II=III \\
\hline \hline a. temís temíis & $\mathrm{W}$ & & $\mathrm{L}$ & $\mathrm{W}$ & \\
\hline b. teméis temíis & $\mathrm{W}$ & $\mathrm{W}$ & & & \\
\hline c. temés temíis & $\mathrm{W}$ & $\mathrm{W}$ & $\mathrm{L}$ & $\mathrm{W}$ & \\
\hline d. vivís vivíis & $\mathrm{W}$ & & $\mathrm{L}$ & $\mathrm{W}$ & \\
\hline e. Xís $\sim$ Xíis & $\mathrm{W}$ & & & & \\
\hline
\end{tabular}

\section{Historical reconstruction, learning and factorial typologies}

In this section, the problems of history and variation converge in the study of the evolution, transformation and transmission of voseo, by means of formal learning theory in Optimality Theory (Tesar \& Smolensky 2000). OT provides the comparative tableau and the recursive algorithms that determine whether a certain set of optima is learnable by a hierarchy of finite constraints or not (Tesar \& Smolensky 2000, Prince 2002). In studying voseo tuteante we want to know which sets among those in (6) are learnable and which are not. This is relevant for the historical linguist as I hypothesize that only those systems that can be learned are the ones that can be transmitted from one generation to the next. Furthermore, the set of learnable systems also sets limits for the typology. Moreover, it only seems natural that a maximum of variability will be progressively approached by the unimpeded evolution of those systems as they reach and spread over new geographical and social environments as well, as they are adopted 
in new conversational settings. In our case study, the four sets of endings are precisely those that are learnable, under the premises that the suffix input for all voseo and vosotros is -is and the system is determined by the interplay of a finite number of basic constraints, among which are *DIPH and II=III.

Formal learning theory in OT is based on the logic of the comparative tableau, see (16) below, where the optima are given to and not determined by the system, as is otherwise normal practice when OT is used to evaluate and select the best input-output correspondence by means of normal tableaux. In a comparative tableau, on the other hand, constraints evaluate a set of optima against any conceivable ${ }^{10}$ contending suboptimal candidate, taken arguably from an infinite set. Each constraint assigns one of three values to any such comparative pair made up of an optimum and a suboptimum. These values are $\mathrm{W}$ for Winner, L for Loser and zero for an equal degree of well-formedness violations or deviations therefrom. W(inner) indicates that the optimum is better than the suboptimum with respect to the relevant constraint by the usual criteria, that is, because the suboptimum violates the constraint and the optimum does not, or, otherwise, because the suboptimum violates the constraint more times than the optimum does. Inversely, a constraint assigns L(oser) to the comparative pair if the optimum fares worse than the suboptimum. When a constraint does not distinguish between optimum and suboptimum, the result is zero. Every annotated comparative pair constitutes an elementary ranking condition, henceforth ERC (Prince 2002). An OT language is a set of optima whose ERC's are mutually compatible. A set of mutually compatible ERC's is a learnable language. Inspecting the set of ERC's of a language, we can determine whether the language in question is learnable or not. Those tests are decisive for the historical linguist, since ex hypothesi only learnable languages can be historically transmitted to the next generation. Sometimes change implies that some ranking must be re-ranked. On other occasions, the change is more radical and requires the revision of input forms, or a morphological reanalysis of inputs. When no reordering is possible, the language in question is likely to be lost with time.

With this simple set of premises, OT provides learning algorithms to determine if a specific set of candidates can ever be declared optimal by at least one hierarchy of a finite number of constraints. That means that such a set of optima is a learnable set. In this section, we will exploit this generative insight in such a way as to claim that only

10 Conceivability of a candidate in OT simply means that a representation can be generated by the generator of the OT system GEN. 
learnable sets can be transmitted to future generations, while unlearnable sets will be lost as time goes by, since learning an OTunlearnable language, if at all possible, would be much more costly in cognitive terms than learning an OT-learnable one. The maximum of potentially learnable sets coincides with the factorial typology. Actual linguistic continua may with time approach this maximum of variability. This seems to have been the case with voseo tuteante. Learnable sets are made up of data that are consistent with realistic learning paths as well as historically plausible diachronic sequences. ${ }^{11}$ In this section, I show how voseo tuteante data follows the paths projected by the set of constraints presented in the previous section. The inputs for the old and the current stages in the historical gap between (7c) and (7d) are virtually identical for all outputs. The relevant constraints responsible for variation, *DIPH and II=III, are the ones that have been active in one way or another in all historical stages of Spanish. For the data under consideration, other constraints like ONS or ${ }^{*} \mathrm{~V}_{\mathrm{i}}$ (high) $\mathrm{V}_{\mathrm{i}}\left(\right.$ high) are always above ${ }^{*} \mathrm{DIPH}$ and II=III in any variety. Assuming that the suffix -is is the only input allows the study of typology, history and learning with the same tools.

\subsection{Decision by sets of Elementary Ranking Conditions}

According to OT premises, a language is learnable if all its data prove optimal under any permutation of a finite set of constraints. The device that lets us decide whether a set of optima is learnable is the collection of all the Elementary Ranking Conditions. An ERC collects the assignment of values $\{\mathrm{W}, \mathrm{L}$, zero $\}$ assigned by each constraint to a certain comparative pair made up of an optimum and a suboptimum. An ERC with one or more L's and no W makes the set of ERC's that it is a part of unlearnable, since consistency demands that all constraints that assign L(oser) to a comparative pair must be dominated by at least one constraint assigning W(inner) somewhere within the same comparative pair. A set of ERC's is also unlearnable if their fusion (Prince 2002) results in a compounded ERC with some $\mathrm{L}$ but no $\mathrm{W}-$ by definition, an impossible ranking. Inspection of ERC's proceeds by recursive elimination of redundant ranking conditions. If inspecting the set of ERC's reveals one or more redundancy-free ERC with only L's, the language under scrutiny is declared unlearnable as it is (Prince 2002). If a set of ERCs is inconsistent, then the inputs, the candidates or the

11 The strength of those results is directly correlated to the degree of similarity between the inputs of the old and the new stages, after changes have taken place. 
constraints used in the ERCs must be revised. If no revision is possible, the language cannot be learned and its future is endangered.

The way recursive algorithms inspect sets of ERCs is straightforward: constraints that have only $\mathrm{W}$ or zero in all the cells are put on top and eliminated for the next steps; all the ERCs where the constraint in question has assigned $\mathrm{W}$ are also ignored in future passes. In (16) we can eliminate $\mathrm{C} 1$, as well as rows $\mathrm{A}$ and $\mathrm{D}$, safely positing $\mathrm{C} 1$ at the top of the ranking.

(16) A hypothetical set of arbitrary ERCs: A, B, C and D

\begin{tabular}{|l||c|c|c|c|}
\hline optimum: & C1 & C2 & C3 & C4 \\
\hline A. $\mathrm{a} \sim \mathrm{b}$ & $\underline{\mathrm{W}}$ & $\mathrm{W}$ & & \\
\hline B. $\mathrm{a} \sim \mathrm{c}$ & & $\mathrm{L}$ & $\mathrm{W}$ & $\mathrm{W}$ \\
\hline C. $\mathrm{a} \sim \mathrm{d}$ & & $\mathrm{W}$ & & $\mathrm{L}$ \\
\hline D. $\mathrm{a} \sim \mathrm{e}$ & $\underline{\mathrm{W}}$ & & $\mathrm{L}$ & \\
\hline
\end{tabular}

The resulting set of non-redundant ranking conditions, once $\mathrm{C} 1$ is put on top, is as in (17). Now we can do the same with C3 and ERC B, since there are no Ls in the column corresponding to constraint C3.

(17) $\mathrm{C} 1>>\ldots$

\begin{tabular}{|l||l|l|l|}
\hline optimum: a & C2 & C3 & C4 \\
\hline \hline B. $\mathrm{a} \sim \mathrm{c}$ & $\mathrm{L}$ & $\underline{\mathrm{W}}$ & $\mathrm{W}$ \\
\hline C. $\mathrm{a} \sim \mathrm{d}$ & $\mathrm{W}$ & & $\mathrm{L}$ \\
\hline
\end{tabular}

The final stage in (18) now contains only an ERC C, after having ranked constraint $\mathrm{C} 3$ above the remaining constraints $\mathrm{C} 2$ and $\mathrm{C} 4$, having eliminated both the column of $\mathrm{C} 3$ and the corresponding ERC B for the next pass.

(18) $\mathrm{C} 1>>\mathrm{C} 3>>$

\begin{tabular}{|l||l|l|}
\hline optimum: $\mathrm{a}$ & $\mathrm{C} 2$ & $\mathrm{C} 4$ \\
\hline \hline C. $\mathrm{a} \sim \mathrm{d}$ & $\underline{\mathrm{W}}$ & $\mathrm{L}$ \\
\hline
\end{tabular}


Now, ERC C can also be eliminated by ranking C2 above C4. That is the last step in our inspection of the initial set of ranking conditions in (16), after which we can safely declare that the language can be learned, supported at the least by the grammar $\mathrm{C} 1 \gg \mathrm{C} 3 \gg \mathrm{C} 2 \gg \mathrm{C} 4$, algorithmically inducted from the dataset of ERCs A, B, C and D in (16).

Next, it will be shown how the sets of the verb endings found in current extant varieties of voseo tuteante, as in (7d), are precisely those sets that can be learned by any grammar based on the constraints *DIPH and II=III in interaction with the two faithfulness constraints MAX-ThV and MAX-X, introduced in section 5. This is, in our opinion, an extremely transparent result for quite an intricate pattern of grammatical variation with a complex historical trajectory. The typology resulting from examining all sets which comply with any ranking that has ONSET and ${ }^{*} \mathrm{~V}(\text { high })_{\mathrm{i}} \mathrm{V}(\text { high })_{\mathrm{i}}$ always on top, are as follows. Undominated ONSET and ${ }^{*} \mathrm{~V}(\text { high })_{\mathrm{i}} \mathrm{V}(\text { high })_{\mathrm{i}}$ make sure that we will not consider candidates containing either ${ }^{*}$ cantá.is with hiatus or either *vivíis or *vivíis with two adjacent identical high vowels (or, rather, vocoids). The only sets respecting ONSET and ${ }^{*} \mathrm{~V}(\text { high })_{\mathrm{i}} \mathrm{V}(\mathrm{high})_{\mathrm{i}}$ are the six sets in (19). The interaction of ${ }^{*} \mathrm{DIPH}$ and II=III with faithfulness reduces the number of possible sets to four, which coincides with the actual typology of voseo tuteante. This coincidence between actual and ideal is, to my mind, an interesting result that must be pursued in earnest in future work.

(19) Learnable and unlearnable datasets for voseo tuteante endings.
a. $\quad\{$-áis, -éis, -ís $\} \quad$ : MAX-X $>>* D I P H, I I=I I I$
b. $\quad$-ás, -ís, -ís $\} \quad$ : *DIPH, II=III $>>$ MAX-Th, MAX-X
c. $\quad\{$-áis, -ís, -ís $\} \quad$ : II=II $>>$ MAX-ThV, MAX-X $>>* D I P H$
d. $\quad$-ás, -és, -ís $\} \quad$ : *DIPH, MAX-ThV $>>$ MAX-X $>>$ II=III
e. $\quad\{$-áis, -és, -ís\} : unlearnable
f. $\quad$ - ás, -éis, -ís\} : unlearnable

\subsection{Unlearnable sets}

In (19), attested and unattested sets of voseo tuteante are clearly segregated, as expected. The sets of attested data coincide with the sets that are learnable, while the sets of unattested data are those which the learning algorithms declare unlearnable. The match between theory and data indicates that the constraints here employed, together with the corresponding optimality-theoretical assumptions about how inputs and outputs relate in general, are the ones that make the strongest hypothesis so far as to the phonological and morphological 
conditions that rule the grammar of the Spanish second person verb endings.

\subsubsection{The first unlearnable set}

The set *\{-áis, -és, -ís $\}$ is absent from the records of voseo tuteante, in spite of the fact that it seemed to be favored by the evidence of the documents from the pre-classical period of Spanish - about the early XVI century (Cuervo 1983, Fontanella de Weinberg 1976). Documental evidence from the late XV and early XVI centuries suggests that the most frequent phonological path would have been the one in (20) below (de Souza 1964), which corresponds with one of the two patterns that are absent in the voseo tuteante of the XX century (DPD, di Tullio 2010, Vázquez-Larruscaín et al. 2019). All the philological work agrees in stating that -áis was the most frequent ending for verbs of the -ar class in the early XVI century, and that -és was the most frequent ending for verbs of the -er class. All previous studies known to us coincide in explaining the patterns attested today as the result of piecemeal analogical relations between the forms from this most frequent pattern, as can be reconstructed from the testimony of the early XVI-century period. Thus, -ás would be considered analogical to -és, and viceversa -éis would be analogical to -áis, for the same reason (Cuervo 1893). However things might have been, no scholar has ever felt the need to explain why the most frequent set from the early XVI century and the apparent basis for future developments ended up nevertheless being discarded in the course of time.

(20) Phonetic trajectories of the endings in the three verb classes

a. Verbs in -ar: -ades >-áes >-áis, also with analogical -ás

b. Verbs in -er: -edes >-ées >-és, also with analogical -éis

c. Verbs in -ir: -ides >-íes >-ís

Nevertheless, the absence of such a set from the extant data in current varieties must be a direct consequence of the grammar we have assumed here, together with the learning theory associated to it. The learning algorithm presented in section 6.1 shows that the set hypothesized in (19e) is unlearnable as a voseo tuteante set, given the constraints employed and the assumptions about the input. In other words, the thesis is that the absence of the set * -áis, -és, -ís\} in any extant variety of voseo tuteante is not a contingent fact of history but a principled gap. When -is is the only input, which is the case from the early XVIII century onwards, and the assignment of thematic vowels is the same in most Spanish varieties, 
as we think is the case, the set * $\{$-áis, -és, -ís $\}$ is no longer a viable one. It is unlearnable, and therefore, historically doomed to extinction.

(21) Contradiction! Both MAX-X >> *DIPH and *DIPH >> MAX-X

\begin{tabular}{|l||c|c|c|c|}
\hline optimum: $\{$-áis, -és, -ís\} & MAX-ThV & MAX-X & ${ }^{*}$ DIPH & II=III \\
\hline \hline a. $\{$-ás, -és, -ís\} & & W & L & \\
\hline b. $\{$-áis, -éis, -ís\} & & L & W & \\
\hline c. $\{$-áis, -ís, -ís\} & $\underline{\text { W }}$ & & & L \\
\hline d. $\{$-ás, -ís, -ís\} & $\underline{\text { W }}$ & W & L & L \\
\hline e. $\{$-ás, -éis, -ís\} & & & & \\
\hline
\end{tabular}

Elementary ranking conditions (21c, d and e) can be removed by ranking MAX-ThV on top, but the remaining (21a and b) are mutually incompatible, as their fusing into a ranking condition with only Ls clearly shows (Prince 2002). That makes this set of endings unlearnable under any possible permutation of the constraints and the relevant theoretical premises about how the grammar works.

\subsubsection{The second unlearnable set}

The second unlearnable set, unlike the previous one, is neither attested in extant varieties nor favored in phonetic terms. Unlike the set discussed in the previous section, this second set has no documental support in the written record of the past either. However, phonetic plausibility has been shown not to be a conclusive argument by itself, according to the conclusions extracted from the previous section, where it was shown that the arguably phonetic expectations of the neogrammarians are not directly connected with the real conditions that may actually have driven the change. As a matter of fact, the learning algorithm clearly shows that this set is unlearnable for the same reasons as the previous one was. Their quite different conditions for survival, if phonetics and written evidence in the past are considered on their own, do not seem to have had any influence on their fate. The same fate awaited both, as both sets of endings were identically doomed as unlearnable by the active grammatical conditions. Both systems are unlearnable in the same way, under the same hypotheses. One of the hypotheses is that the input suffix for all varieties is -is. Another strong hypothesis is that the set of constraints is the one discussed in section 5. The final hypothesis is that the grammar of a language is an OT device, and that formal OT learning theory can 
determine whether a set of candidates is learnable or not. The negative diagnostics are the same for (22) as they were for (21), above. Nothing much needs to be added now, when learnability conditions determine the fate of any set of desired optima.

Contradiction! Both MAX-X >> *DIPH and *DIPH $>>$ MAX-X

\begin{tabular}{|l||c|c|c|c|}
\hline optimum: $\{$-ás, -éis, -ís\} & MAX-ThV & MAX-X & *DIPH & II=III \\
\hline \hline a. $\{$-ás, -és, -ís\} & & W & L & \\
\hline b. $\{$-áis, -éis, -ís\} & & L & W & \\
\hline c. $\{$-áis, -ís, -ís\} & $\underline{\text { W }}$ & & & L \\
\hline d. $\{$-ás, -ís, -ís\} & $\underline{W}$ & W & L & L \\
\hline e. $\{$-áis, -és, -ís\} & & & & \\
\hline
\end{tabular}

\subsection{The learnable sets}

I show in this section that the actually attested sets are those that are perfectly learnable by the algorithm under the conditions argued for in this paper.

\subsubsection{The first learnable set}

The first learnable set of voseo tuteante verb endings coincides with the set that is normative for voseo reverente and the second person plural vosotros. This is the set with the maximum number of diphthongs, that is, set (19a), with \{-áis, -éis, - ís\}. The fact that the set with diphthongs is the one that has become the normative set for vosotros is consistent with the idea that normative varieties are usually characterized by maximal faithfulness. The set $\{$-áis, - éis, -ís\} is the set that respects the maximum level of faithfulness to the input, while simultaneously complying with the constraint against a sequence of two identical high vowels $* \mathrm{~V}(\text { high })_{\mathrm{i}} \mathrm{V}(\text { high })_{\mathrm{i}}$, never violated in any variety of Spanish. The consistency of the relevant elementary rankings, given in (23), is quite transparent. It is easy to see that the general MAX-X does the whole job singlehandedly, redundantly reinforced by MAX-ThV, the ranking of which is therefore irrelevant in this grammar, as its effects all fall under the umbrella of a highly-ranked MAX-X. 
(23) MAX-X >> *DIPH, II=II

\begin{tabular}{|l||c|c|c|c|}
\hline optimum: $\{$-áis, -éis, -ís\} & MAX-ThV & MAX-X & $*$ DIPH & II=III \\
\hline \hline a. $\{$-ás, -és, -ís\} & & $\underline{\mathrm{W}}$ & L & \\
\hline b. $\{$-áis, -és, -ís\} & & $\underline{\mathrm{W}}$ & $\mathrm{L}$ & \\
\hline c. $\{$-áis, -ís, -ís\} & $\mathrm{W}$ & $\underline{\mathrm{W}}$ & $\mathrm{L}$ & L \\
\hline d. $\{$-ás, -ís, -ís\} & $\mathrm{W}$ & $\underline{\mathrm{W}}$ & $\mathrm{L}$ & L \\
\hline e. $\{$-ás, -éis, -ís\} & & $\underline{\mathrm{W}}$ & $\mathrm{L}$ & \\
\hline
\end{tabular}

\subsubsection{The second learnable set}

The second learnable set contains only monophthongs, that is, the three thematic vowels. This set has become the most characteristic pattern of voseo tuteante. As shown in (4) above, these monophthong endings have clear historical precedents already in the XV and XVI centuries, but they were gradually confined to the non-standard varieties varieties of Spanish already at the end of the XVI and early XVII centuries. Today, outside Argentina, this set is not recognized as a normative variant either, in spite of being the national vernacular for a number of countries in Central America and the region of Rio de la Plata. The set is maximally faithful to the thematic vowel but sacrifices the vowel of the ending -is to satisfy the constraint against diphthongs and sequences of adjacent vowels. The tableau in (24) reveals that both MAX-ThV and *DIPH do the whole job in eliminating redundancy in the set of ERCs.

(24) *DIPH, MAX-ThV >> MAX-X, II=III

\begin{tabular}{|l|c|c|c|c|}
\hline optimum: $\{$-ás, -és, -ís\} & MAX-ThV & MAX-X & $*$ DIPH & II=III \\
\hline \hline a. $\{$-ás, -ís, -ís\} & $\underline{\text { W }}$ & & & L \\
\hline b. $\{$-áis, -és, -ís\} & & L & $\underline{\text { W }}$ & \\
\hline c. $\{$-áis, -eís, -ís\} & & L & $\underline{\text { W }}$ & \\
\hline d. $\{$-áis, -ís, -ís\} & W & L & $\underline{\text { W }}$ & L \\
\hline e. $\{$-ás, -éis, -ís\} & & L & $\underline{\text { W }}$ & \\
\hline
\end{tabular}




\subsubsection{The third learnable set}

The third learnable set $\{$-áis, -ís, -ís\} is a mixed variety. These varieties are always non-standard. They are found not only in voseo tuteante, but also in varieties of Sephardic Spanish in Northern Africa, as well as in a good number of traditional dialects in Spain up to the XX century. They are also found in documents from the pre-classical period of Spanish in the early Renaissance (see Fontanella de Weinberg 1976 for a detailed overview over the spread and the variation of mixed types). So-called mixed varieties characteristically neutralize the allomorphic distinctions between second and third class verbs in the present tense, which is, for that matter, a levelling widely attested among the Romance languages (Lauschberg 1962). This levelling, however, is always unknown to normative Spanish. The combination of the levelled -ís with the diphthong -áis (typical of Chilean voseo tuteante) is, on the other hand, the most faithful choice among the mixed types. When assessing \{-áis, -ís, -ís\}, the constraint II=III assigns W to (25a, b, c and e) and, therefore, the corresponding ERCs can be eliminated. MAX-X takes care of the remaining ERC (25d), such that the diphthong of the ending -áis is preferred over its competing -ás rival. The ordering of MAX-ThV, at this point, is irrelevant, as far as it remains dominated by II=III.

(25) II=III >> MAX-X >> *DIPH

\begin{tabular}{|l||c|c|c|c|}
\hline optimum: $\{$-áis, -ís, -ís\} & MAX-ThV & MAX-X & *DIPH & II=III \\
\hline \hline a. $\{$-ás, -és, -ís\} & L & W & L & $\underline{\text { W }}$ \\
\hline b. $\{$-áis, -és, -ís\} & L & & & $\underline{\mathrm{W}}$ \\
\hline c. $\{$-áis, -eís, -ís\} & L & L & W & $\underline{\text { W }}$ \\
\hline d. $\{$-ás, -ís, -ís\} & W & $\underline{\text { W }}$ & L & \\
\hline e. $\{$-ás, -éis, -ís\} & L & & & $\underline{W}$ \\
\hline
\end{tabular}

\subsubsection{The fourth learnable set}

The fourth learnable set is the second mixed type $\{$-ás, -és, -ís\}. The constraint II=III, always strong in mixed types, does most of the work, eliminating ERCs (26 a, b, c, and e). ERC (26d) is now consistent if *DIPH can be dominated by both MAX-X ${ }^{12}$ and MAX-ThV, but the actual

\footnotetext{
12 Now MAX-ThV plays a role in preferring \{-ás, -ís, -ís\} to \{-ís, -ís, -ís\}, but since MAX-X is dominated by all relevant constraints, and MAX-ThV is a more stringent version than the general MAX-X, the ranking of MAX-ThV is actually irrelevant. The only condition is that II=III dominates MAX-ThV in all mixed types.
} 
ranking of MAX-ThV with respect to MAX-X is irrelevant, provided that II=III is on top. As in section 6.3.3, MAX-ThV must be dominated by II=III, which is the invariant condition for all mixed types of voseo tuteante.

(26) II=III, *DIPH >> MAX-X

\begin{tabular}{|l||c|c|c|c|}
\hline optimum: $\{$-ás, -ís, -ís\} & MAX-ThV & MAX-X & *DIPH & II=III \\
\hline \hline a. $\{$-ás, -és, -ís\} & L & & & $\underline{\mathrm{W}}$ \\
\hline b. $\{$-áis, -és, -ís\} & L & L & $\underline{\mathrm{W}}$ & $\underline{\mathrm{W}}$ \\
\hline c. $\{$-áis, -eís, -ís\} & $\mathrm{L}$ & $\mathrm{L}$ & $\underline{\mathrm{W}}$ & $\underline{\mathrm{W}}$ \\
\hline d. $\{$-áis, -ís, -ís\} & $\mathrm{W}$ & $\mathrm{L}$ & $\underline{\mathrm{W}}$ & \\
\hline e. $\{$-ás, -éis, -ís\} & $\mathrm{L}$ & $\mathrm{L}$ & $\underline{\mathrm{W}}$ & $\underline{\mathrm{W}}$ \\
\hline
\end{tabular}

\section{Conclusions}

This revision of our understanding of voseo tuteante is a formal inquiry into which active conditions shaped the pattern and how those active conditions may have determined its evolution over the centuries. More specifically, what the analysis reveals is the historical transmission from what must have been the last stages of the classical voseo in all registers around the end of the XVII century, today preserved as voseo reverente. This voseo reverente is, not surprisingly, the most faithful variety. The verb allomorphs of this variety coincide with a relatively marginal variety of voseo tuteante. The only distinction is pragmatic, as voseo tuteante is used only for informal address. Voseo tuteante is only recognized by the pronoun paradigm.

(27) Contrast: classical voseo and voseo tuteante (diphthong pure).

a. Vos, señora, no debéis preocuparos por ello.

'You, milady, should not worry about it' (voseo reverente)

b. Vos, amigo, no debéis preocuparte por ello.

'You, mate, should not worry about it' (voseo tuteante diptongado puro ${ }^{13}$ )

On the other hand, there is also a minimally faithful voseo tuteante with both monophthongs and neutralization of endings in the second

\footnotetext{
13 This terminology is taken from Vázquez-Larruscaín et al. (2019).
} 
and third verb classes in -er and -ir, respectively. This system, only attested outside Castilian-Spanish proper, must have been already in place since the first period of settlement and conquest, among other things because it is found in conservative varieties of Sephardic Spanish. Thus, minimal and maximal faithfulness must have set the boundaries for the original variability space in the XVI century. For that period, one must assume an even larger space of variation than what is found today in the otherwise larger geographical space of the Spanishspeaking world, see (7a) above. To my mind, the decisive moment that limited variation takes place during the XVI and the XVII centuries, when the suffix -is definitively replaces the original suffix -des, regularly derived from Latin -tis. With this reinterpretation of the verb ending, the new factorial typology was reduced to the four sets of verb endings that today survive in voseo tuteante varieties. My conclusion is that this state of affairs is determined by the structural possibilities of a factorial typology which is nothing but the different rankings afforded to a finite set of constraints. This systemic approach rationalizes the history of voseo in its basics, with contact to both variability and learnability considerations. To my mind, this is a much more satisfactory way of looking at things than the mere inspection of the fate of the different endings as separate events. The variation space is readily visualized with a diamond-like lattice, where faithfulness is maximal on top and minimal at the bottom. Most typical systems are found in-between. To the left is the prototypical one, well established in both the countries of the Río de la Plata and Central America, with monophthongs in the endings, a pure system with clear distinctions between the three verb classes (Donni de Mirande 1992, Di Tullio 2010). To the right is the Chilean prototype, a mixed system, where II=III is on top (Morales Pettorino 1999). This system is also scattered in the interior regions all the way from Northwestern Argentina to Ecuador (DPD, Quesada 2000, Carricaburo 2015, Vázquez-Larruscaín et al. 2019).

(28) Factorial typology of voseo tuteante

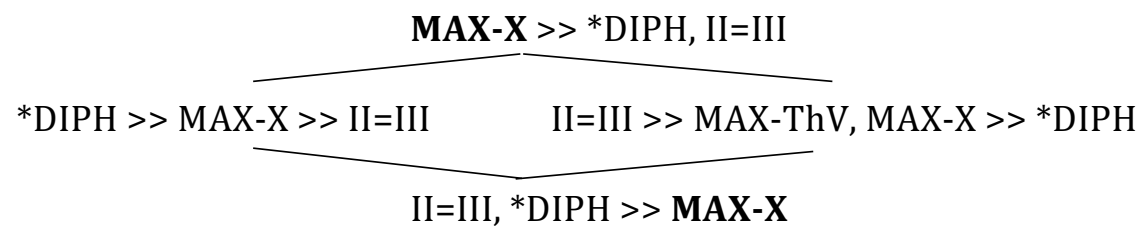




\section{Comments invited}

PiHPh relies on post-publication review of the papers that it publishes. If you have any comments on this piece, please add them to its comments site. You are encouraged to consult this site after reading the paper, as there may be comments from other readers there, and replies from the author. This paper's site is here:

https://doi.org/10.2218/pihph.5.2020.5299

\section{Acknowledgements}

This paper is based on a poster presented at the Fourth Edinburgh Symposium on Historical Phonology, held 9-10 December 2019. I would like to express my gratitude to the organizers and the rest of the participants, and especially to those who contributed with enlightening and enriching comments and questions. Errors and inconsistencies that remain are certainly mine.

\section{Author contact details}

Miguel Vázquez-Larruscaín

Institute for Language and Literature

University of Southeastern Norway

Halvard Eikas pl. 1

Bø i Telemark, N-3800 Norway

miguel.vazquez-larruscain@usn.no

\section{References}

$\mathrm{AAL}=$ Academia Argentina de Letras.

BAAL = Boletín de la Academia Argentina de Letras. 1982. El voseo. XLVII. 290-295.

Bertolotti, V. 2015. A mí de vos no me llama ni usted ni nadie. Sistemas e historia de las formas de tratamiento en la lengua española de América. Ciudad de México: Universidad Nacional Autónoma de México.

Brown, R. \& A. Gilman. 1960. The Pronouns of Power and Solidarity. In T.A. Sebeok (ed.), Style in Language, 253-276. Cambridge. MA: M.I.T Press.

Calderón Campos, M. 2010. Variantes formales y valores semánticos de (V)os(otros) en la diacronía del español. In R.M. Castañer et al. 
(eds.), De moneda nunca usada. Estudios dedicados a José María Enguita Utrilla, 135-147.

Carricaburo, N. 2015. Las fórmulas del tratamiento en el español actual. Madrid: Arco Libros.

Cuervo, R.J. 1893. Las segundas personas del plural en la conjugación castellana. In Romania vol. 22, 85. 71-86.

Cuervo, R.J. 1911. Las segundas personas del plural en la conjugación castellana, 2nd edition. In R.J. Cuervo (ed.). 1954. Obras. Bogotá: Instituto Caro y Cuervo.

Cuervo, R.J. 1948. Disquisiciones sobre filología castellana. Buenos Aires: El Ateneo.

Donni de Mirande, N.E. 1992. El sistema verbal en el español de la Argentina: rasgos de unidad y de diferenciación dialectal. Revista de Filología Española LXXII 3/4. 655-670.

DPD = Diccionario Panhispánico de Dudas. 2005. Real Academia Española.

Dworkin, St. N. 1988. The interaction of phonological and morphological processes: the evolution of the Old Spanish second person plural verb endings. Romance Philology XIII. 144-155.

Ferguson, Ch. A. 1959. Diglossia Word 15(2). 325-340.

Fontanella de Weinberg, M.B. 1976. Analogía y confluencia paradigmática en formas verbales del voseo. In Thesaurus XXXII.

Fontanella de Weinberg, M.B. 1977. La constitución del paradigma pronominal del voseo. In Thesaurus XXXIII. 227-239.

Fontanella de Weinberg, M.B. 1999. Sistemas pronominales de tratamiento usados en el mundo hispánico. In Bosque, I \& V. Demonte (eds.) Gramática descriptiva de la lengua española, vol. I, 1399-1426. Madrid: Espasa Calpe.

De Granda, G. 1978. Las formas verbales diptongadas en el voseo hispanoamericano. Una interpretación sociohistórica de datos dialectales. En Nueva Revista de Filología Hispánica XXVII. 80-92.

De Lacy, P. 2006. Markedness: reduction and preservation in phonology. Cambridge: Cambridge University Press.

Lapesa, R. 1970. Las formas verbales de segunda persona y los orígenes del voseo. In Actas del Tercer Congreso Internacional de Hispanistas. Mexico City: El Colegio de México.

Lapesa, R. 1981. Historia de la lengua española. 9th edition. Madrid: Gredos.

Lausberg, H. 1962. Romanische Sprachwissenschaft. Band 2. Berlin: de Gruyter.

Malkiel, Y. 1949. The contrast tomáis tomávades, queries queríades in Classical Spanish. The Hispanic Review 17(2). 159-165.

Morales Pettorino, F. 1999. Panorama del voseo chileno y rioplatense. In Homenaje al profesor Ambrosio Rabanales. BFUCh XXXVII. 835-848. 
NGLE = Nueva Gramática de la Lengua Española. 2009. Madrid: Espasa.

Páez-Urdaneta, I. 1981. Historia y geografía hispanoamericana del voseo. Caracas: La casa de Bello.

Prince, A. 1997. Stringency and Paninian hierarchies. Handout at 1997 LSA Linguistic Institute.

Prince, A. 2002. Arguing OT. Ms. Rutgers University.

Prince, A. \& P. Smolensky. 2004. Optimality Theory. Cambridge, MA: MIT Press.

Quesada, M.A. 2000. El español de América. Cartago: Editorial Teconológica de Costa Rica.

Rini, J. 1996. The vocalic formation of the Spanish verbal suffixes -áis/ás, -éis/és, -ís, -óis/-ós: a case of phonological or morphological change? Ibero-Romania 44. 1-16.

Rona, J.P. 1967. Geografía y morfología del voseo. Porto Alegre: Pontifícia Universidade de Católica do Rio Grande do Sul.

De Souza, R. 1964. Desinencias verbales correspondientes a la persona vos/vosotros en el Cancionero General (Valencia, 1511). Filología, año X. 1-16.

Tesar, B. \& P. Smolensky. 2000. Learnability in Optimality Theory. Cambridge, MA: MIT Press.

Di Tullio, A. 2010. El voseo argentino en épocas del Bicentenario. RASAL vol.2. 47-71.

Vázquez-Larruscaín, M., M. Teira \& A. Sieder. 2019. Terminología y parámetros del voseo: una definición del voseo nacional argentino. Borealis: an International Journal of Hispanic Linguistics 8(2). 295-319.

Zamora Vicente, A. 1960. Dialectología española. Gredos: Madrid. 